\title{
CLEAN AGRICULTURE FOR THE SAFE PRODUCTION OF DATE PALM FRUIT (PHOENIX DACTYLIFERA L. CV. SEWI) UNDER EGYPTIAN CONDITIONS
}

\author{
ASEERI, I. A. ${ }^{1}-$ OMAR, A. K. ${ }^{2,3 *}-$ SHAREEF, H. J. ${ }^{4}-$ ALY, K. M. ${ }^{5}$ \\ ${ }^{1}$ Faculty of Science and Arts, Muhayil Asir King Khalid University, Kingdom of Saudi Arabia \\ ${ }^{2}$ Institute of Research and Consulting, King Fasil University, Kingdom of Saudi Arabia \\ ${ }^{3}$ Horticulture Dept., Kafresheikh University, Faculty of Agriculture, Kafr El-Sheikh 33516, \\ Egypt \\ ${ }^{4}$ Dept. of Date Palm Research Centre, University of Basrah, Basrah, Iraq \\ ${ }^{5}$ Date Palm Research and Development, Agricultural Research Centre, Giza, Egypt \\ *Corresponding author \\ e-mail: alaa.omr@agr.kfs.edu.eg,akomar@kfu.edu.sa;phone: +20-109-740-8240 \\ (Received $3^{\text {rd }}$ Jan 2021; accepted $10^{\text {th }}$ Jun 2021)
}

\begin{abstract}
The excessive use of nitrogen fertilization increases soil acidity, and contaminates the environment. It also increases heavy metals concentration in the plant with a serious threat to human health. A wide variety of microorganisms can be used as alternatives to minimize mineral fertilization. This study was conducted during the 2017 and 2018 seasons on 'Sewi' date palm grown under Egyptian conditions, to evaluate the effect of mineral-, organic-, and bio-fertilization on fruit yield and quality, as well as to encourage growers to switch to organic- and bio-fertilization. Fertilization was applied in six treatments; 1) $100 \%$ mineral NPK, 2) 100\% manure, 3) 100\% Azotobacter chroococcum [Az14], Bacillus megatherium var. phosphaticum [B6], 4) Bacillus circulans [B4]), 5) 50\% manure $+100 \%$ bio-fertilizer, and 6) $50 \%$ mineral NPK $+100 \%$ bio-fertilizer, plus the control (no fertilization). Results indicated that $50 \%$ manure $+100 \%$ bio-fertilizer and $50 \%$ NPK $+100 \%$ bio-fertilizer improved yield and fruit quality. Fertilization with $50 \%$ manure $+100 \%$ bio-fertilizer led to high values of leaflet area, yield, fruit and flesh weight, soluble solids content, vitamin C, and total sugars, but the lowest fruit firmness. While $50 \%$ NPK $+100 \%$ bio-fertilizer led to the highest values of new leaves, leaf length, fruit length and diameter, and reducing sugars. Results indicated that non-mineral fertilizers improved yield and fruit quality compared to the mineral ones, and this was also more acceptable to the consumers.
\end{abstract}

Keywords: organic fertilizer, SSC, clean agriculture, date palm, fruit quality, Azotobacter chroococcum, bio-fertilizers, Bacillus circulans

\section{Introduction}

Egypt is a subtropical country which lies between $22^{\circ}$ and $31^{\circ}$ North latitudes and between $25^{\circ}$ and $35^{\circ}$ East longitudes. Its climate (comprising a mild and wet winter from November to April and a hot and dry summer from May to October) is suitable for the production of many field and horticultural crops (Directorate of Intelligence, 2011). The west delta and the New Valley are the main production regions of semi-dry date cultivars which have moderate moisture content (30-45\%) and medium sugar concentrations (45-50\%). Typical semi-dry cultivars are 'Siwi', 'Amri', 'Agalni', and 'Saidy' that require about 2700-2900 heat units during the growing season (MayOctober) with an average daily temperature higher than $80-84^{\circ} \mathrm{F}\left(27-29^{\circ} \mathrm{C}\right)$. Upper Egypt and the southern parts of the New Valley are the main production regions of dry 
date cultivars which have low moisture content (15-20\%) and high sugar concentrations (65-70\%). Dry date cultivars include 'Sultani', 'Barakawi', 'Abrimi', 'Sakouti', 'Barmatoda', 'Melkabi', 'Gondeila', 'Gargoda', 'Digna', and 'Shamia' that require about 3600-4300 heat units during the growing season (May-October) with an average daily temperature higher than $104-113^{\circ} \mathrm{F}\left(40-45^{\circ} \mathrm{C}\right)(\mathrm{Riad}, 1993)$.

Date palm, Phoenix dactylifera L., is one of the most common domestic tree fruits in the Middle East and North Africa region. Fruit plays a major role in human nutrition (Harhash and Abdel-Nasser, 2010; Sarrwy et al., 2012). The total crop yield in Egypt is estimated to be 1590414 tons of fresh, semi-dry and dry dates (FAO, 2019). Recently, chemical pesticides and fertilizers have been extensively used in tree fruit production (Sarker, 2012), which led to several problems and poor cropping systems. The excessive application of mineral nitrogen fertilizers has increased soil acidity, and contaminated groundwater and the surrounding environment. It has also weakened plant roots making them subjected to several diseases (Ayed, 2002). The price of nitrogen fertilizers has almost doubled during the last 3-4 years, which increases the need for cheaper sources of nitrogen (Andrews et al., 2010). Incorporation of organic matters into soil improved its structure, water retention (Alvarez and Alvarez, 2000), and infiltration rates (Carter, 2002; Bot and Benites, 2005). Organic fertilization may improve the physical and biological characteristics of the soil, and may also serve as a source of mineral nutrients (El-Koumey and AbuAgwa, 1993; Wander, 2004). The combination of organic and inorganic sources of nutrients is essential to maintain good soil characteristics and to increase nutrient use efficiency (Dev, 2006). The main challenge when converting a conventional farm into an organic one is to have a sufficient $\mathrm{N}$ amount that ensures an acceptable crop yield (Hue and Silva. 2000; Galantini and Rosell, 2006; Iqbal, 2012). Recently, biofertilization has an important component of integrated nutrient supply to improve yield and its components through environment-friendly fertilizers (Marozsán et al., 2005; Franche, et al., 2009). Soil microorganisms promote the supply of important nutrients and have a crucial role for overall plant productivity (Garg, 2001; Baca and Elmerich, 2007). Using bio-fertilizers is a better option to reduce agrochemical inputs, and helps maintain soil fertility and strength (Chang. and Young. 1999). An increasing number of farmers are switching to organic and bio-fertilizers since they were found to be gentler on the soil (Cheng and Chung, 2004). Consequently, the value of organic sources has also increased in an increasingly eco-conscious world (Subba Rao, 1982.). The species of Azotobacter are known to fix natural atmospheric nitrogen in soil rhizosphere, thereby contributing towards nitrogen availability for the plants. Azotobacter chroococcum was isolated and used previously as a bio-fertilizer to improve the quantity and the quality of mango crop (Ahmad et al., 2004; Malik, 2009). Soil quality has also improved with the addition of the environment-friendly fertilizers (Young et al., 2003). Bio-fertilizers have also contributed in reducing the negative effect of global warming (Delima, 2012). Microorganisms including Azotobacter, as non-symbiotic nitrogen fixers, were isolated from various ecosystems, and their performance under laboratory and field conditions were tested (Garg, 2001; Baca and Elmerich, 2007; Franche, et al., 2009; Hidayatullah et al., 2018; Abd ElRazek et al., 2018). The enhancement and maintenance of soil fertility through microorganisms is an important goal in sustainable agriculture (Liou and Young, 2002). Hence, several microorganisms can be used as alternatives to chemical fertilizers to minimize the use of mineral fertilizers (Tsai et al., 2004). 
The aim of the present work was to access the impact of different fertilizers (minerals, organic, bio-fertilizer, and their combinations) on fruit yield and quality of Sewi date palm grown under the Egyptian conditions.

\section{Materials and methods}

\section{Microbial strains}

Non-symbiotic nitrogen-fixing bacteria, Azotobacter chroococcum (Az14), phosphate dissolving bacteria, Bacillus megatherium var. phosphaticum (B6), and potassium dissolving bacteria, Bacillus circulans (B4), were obtained from Bacteriology Lab, Sakha Agricultural Research Station. Pure cultures were maintained on Jensen's medium (Jensen, 1951), modified Bunt and Rovira medium (Abdel-Hafez, 1966), and nutrient agar medium (Atlas, 1997), respectively.

\section{Preparation of inoculum}

The sterilized carrier material (peat moss) in sealed bags has aseptically injected with a suitable amount of broth culture (107-108 CFU ml-1). From each inoculum, $3 \mathrm{~kg} / 4200 \mathrm{~m}^{2}$ was used after mixed with suitable amount of sandy soil of fine clay soil, then strew around the plant.

\section{Plant material}

This experiment was conducted during 2017 and 2018 seasons on eighteen- 11 years old 'Sewi' date palms, uniform in size and vigor, grown in sandy loam soil at $7 \times 7 \mathrm{~m}$ spacing in a private groove at El-Dakhla Oasis, New Valley Governorate, Egypt. Laboratory work was conducted at the Horticulture Department, Faculty of Agriculture, Kafrelsheik University, Egypt. Soil analysis (Table 1) was conducted according to Wilde et al. (1985).

Table 1. Soil analysis of research field

\begin{tabular}{|c|c|c|}
\hline Parameters & Before treatment & After treatment \\
\hline Silt \% & 5.20 & 6.00 \\
\hline Clay $\%$ & 15.30 & 15.84 \\
\hline Sand $\%$ & 77.80 & 72.40 \\
\hline Texture class & Sandy loam & Sandy loam \\
\hline $\mathrm{pH}$ & 8.2 & 7.76 \\
\hline $\mathrm{EC}(\mathrm{ds} \backslash \mathrm{m})$ & 0.38 & 0.22 \\
\hline $\mathrm{CaCO}_{3} \%$ & 2.1 & 2.33 \\
\hline \multicolumn{3}{|c|}{ Soluble cations (meq $\backslash$ ) } \\
\hline $\mathrm{Ca}^{+2}$ & 2.0 & 1.2 \\
\hline $\mathrm{Mg}^{+2}$ & 0.8 & 0.8 \\
\hline $\mathrm{Na}^{+1}$ & 1.0 & 0.68 \\
\hline $\mathrm{K}^{+1}$ & 0.55 & 0.18 \\
\hline \multicolumn{3}{|c|}{ Soluble anions (meq $\backslash$ ) } \\
\hline $\mathrm{Cl}^{-1}$ & 0.8 & 0.4 \\
\hline $\mathrm{CO}_{3}{ }^{-2}$ & 0.0 & 0.0 \\
\hline $\mathrm{HCO}_{3}{ }^{-1}$ & 0.8 & 0.8 \\
\hline $\mathrm{SO}_{4}$ & 2.75 & 1.66 \\
\hline
\end{tabular}


Six fertilization treatments in five replicates (Palm/replicate) were applied as follow; $100 \%$ Mineral fertilizer (NPK), 100\% Organic fertilizer (manure), 100\% Biofertilizer (Azotobacter chroococcum strain EB2), 50\% Organic $+100 \%$ Biofertilizer, $50 \%$ Mineral $+100 \%$ Biofertilizer, and the control, as shown in Table 2 .

Table 2. Treatments

\begin{tabular}{|c|c|c|c|c|c|c|}
\hline \multirow[b]{2}{*}{ No. } & \multirow[b]{2}{*}{ Treatments } & \multicolumn{3}{|c|}{ Mineral fertilization } & \multirow{2}{*}{$\begin{array}{c}\text { Organic } \\
\text { fertilization } \\
\text { (kg/tree/year) }\end{array}$} & \multirow{2}{*}{$\begin{array}{c}\text { Bio-fertilization } \\
\text { (ml/tree/year) }\end{array}$} \\
\hline & & $\begin{array}{c}\mathrm{N} \\
\text { (g/tree/year) }\end{array}$ & $\begin{array}{c}\mathbf{P} \\
\text { (g/tree/year) }\end{array}$ & $\begin{array}{c}\mathrm{K} \\
\text { (g/tree/year) }\end{array}$ & & \\
\hline $\mathrm{T}_{1}$ & $100 \%$ Mineral & 1200 & 500 & 2000 & 0 & 0 \\
\hline $\mathrm{T}_{2}$ & $100 \%$ Organic & 0 & 0 & 0 & 100 & 0 \\
\hline $\mathrm{T}_{3}$ & $100 \%$ Bio-fertilizer & 0 & 0 & 0 & 0 & 100 \\
\hline $\mathrm{T}_{4}$ & $50 \%$ Organic $+100 \%$ Bio-fertilizer & 0 & 0 & 0 & 50 & 100 \\
\hline $\mathrm{T}_{5}$ & $50 \%$ Mineral $+100 \%$ Bio-fertilizer & 600 & 250 & 1000 & 0 & 100 \\
\hline $\mathrm{T}_{6}$ & Control & 0 & 0 & 0 & 0 & 0 \\
\hline
\end{tabular}

\section{Fertilization type and rate of application}

Mineral fertilizer

Nitrogen $(\mathrm{N})$ in the form of ammonium sulphate $(20.5 \% \mathrm{~N})$ was added in three different rates; $400 \mathrm{~g} \times 3\left(\mathrm{~T}_{1}\right)$ and $200 \mathrm{~g} \times 3\left(\mathrm{~T}_{5}\right)$ during the last week of February, last week of April, and last week of May of both seasons. Phosphorus (P) in the form of super phosphate $\left(25.47 \% \quad \mathrm{P}_{2} \mathrm{O}_{5}\right)$ was added in one rate; $400 \mathrm{~g} \times 1\left(\mathrm{~T}_{2}\right.$ and $\left.\mathrm{T}_{6}\right)$ during the last week of October of both seasons. Potassium $(\mathrm{K})$ in the form of potassium sulphate $\left(50 \% \mathrm{~K}_{2} \mathrm{O}\right)$ was added in two rates; $500 \mathrm{~g} \times 2\left(\mathrm{~T}_{2}\right.$ and $\left.\mathrm{T}_{6}\right)$ during the last week of April and the last week of May of both seasons.

\section{Organic fertilizer}

Manure contained approximately $0.49 \% \mathrm{~N}, 0.17 \% \mathrm{P}$, and $0.37 \% \mathrm{~K}$ was added one time in the following rates; $50 \mathrm{~kg} \times 1\left(\mathrm{~T}_{2}\right)$ and $25 \mathrm{~kg} \times 1\left(\mathrm{~T}_{4}\right)$ during the last week of October of both seasons.

\section{Biofertilizer}

Azotobacter chroococcum (Az14), Bacillus megatherium var. phosphaticum (B6), and Bacillus circulans $\left(\mathrm{B}_{4}\right)$ bacteria were added in a rate of $70 \mathrm{ml}\left[10^{8} \mathrm{cfu} / \mathrm{ml}\right]\left(\mathrm{T}_{3}\right)$ at the same time nitrogen and organic fertilization were applied in both seasons (Table 2).

\section{Control}

No fertilization $\left(\mathrm{T}_{6}\right)$.

\section{Parameters}

Leaflet area $\left(\mathrm{cm}^{2}\right)$ using leaf area meter (LI-COR LI-3100, Nebraska, USA). Yield was estimated as bunch weight per treatment.

\section{Fruit physical and chemical characteristics}

Samples of 30 dates were randomly picked from each bunch of each treated palm to determine the physical characteristics of the fruit (weight $[\mathrm{g}]$, length $[\mathrm{cm}]$, diameter 
[cm], and flesh weight $[\mathrm{g}])$. The same fruit samples were used to estimate soluble solids content [SSC \%] of fruit juice using hand-held refractometer; vitamin C (A.O.A.C., 1980); tannins content, determined according to the method of Winton and Winton (1958); total sugars, determined in methanol extract using phenol sulphoric acid method and the percentage was calculated on dry weight basis according to Dubois et al. (1956); and reducing sugars were determined in methanol extract according to A.O.A.C. (1980).

\section{Statistical analysis}

Data were analyzed in one-way ANOVA using SAS program (SAS Institute Inc., 2000). Mean comparisons were carried out using least significant difference (LSD) test at $\mathrm{P} \leq 0.05$ (Snedecor and Cochran, 1977).

\section{Results}

\section{Leaf length, leaf area and number of new leaves}

Results presented in Table 3 showed significant differences between all treatments and the control. Treatment 5 (Organic 50\% + Bio 50\%) recorded the highest values of leaf length and area during both seasons.

Table 3. Effect of different sources of fertilizer on leaf length ( $m)$, number of leaflet, leaflet area $\left(\mathrm{cm}^{2}\right)$ and number of new leaves of "Sewi" date palm during 2017 and 2018 seasons

\begin{tabular}{|c|c|c|c|c|c|c|c|c|}
\hline \multirow[t]{2}{*}{ Treatments } & \multicolumn{2}{|c|}{ Leave length $(\mathrm{m})$} & \multicolumn{2}{|c|}{ No- leaflet } & \multicolumn{2}{|c|}{ Leaflet area $\left(\mathrm{cm}^{2}\right)$} & \multicolumn{2}{|c|}{ No-new leaves } \\
\hline & 2017 & 2018 & 2017 & 2018 & 2017 & 2018 & 2017 & 2018 \\
\hline 100\% Mineral (T1) & $4.45 b$ & $4.68 \mathrm{~b}$ & $170.49 \mathrm{a}$ & $178.33 \mathrm{a}$ & $157.79 \mathrm{c}$ & $173.23 b$ & $24.67 \mathrm{~d}$ & $25.33 \mathrm{ab}$ \\
\hline $100 \%$ Organic (T2) & $4.45 b$ & $4.73 b$ & $166.10 \mathrm{a}$ & $178.00 \mathrm{ab}$ & $171.80 \mathrm{~b}$ & $178.59 \mathrm{~b}$ & $21.33 \mathrm{~d}$ & $23.67 \mathrm{c}$ \\
\hline 100\% Bio-fertilizer (T3) & $4.37 \mathrm{~b}$ & $\mathrm{c} 4.58 \mathrm{c}$ & $171.09 \mathrm{a}$ & $178.00 \mathrm{ab}$ & $139.54 d$ & $172.25 b$ & $24.67 b$ & $23.00 \mathrm{c}$ \\
\hline $\begin{array}{c}50 \% \text { Organic }+100 \% \\
\text { Bio-fertilizer (T4) }\end{array}$ & $4.40 \mathrm{~b}$ & $4.77 \mathrm{~b}$ & $168.36 \mathrm{ab}$ & $179.00 \mathrm{a}$ & $168.73 b$ & $176.03 b$ & $26.00 \mathrm{a}$ & $25.67 \mathrm{a}$ \\
\hline $\begin{array}{l}50 \% \text { Mineral }+100 \% \\
\text { Bio-fertilizer (T5) }\end{array}$ & $4.70 \mathrm{a}$ & $4.97 \mathrm{a}$ & $171.54 \mathrm{a}$ & $181.67 \mathrm{a}$ & $195.31 \mathrm{a}$ & $198.87 \mathrm{a}$ & $22.67 \mathrm{c}$ & $24.00 \mathrm{bc}$ \\
\hline Control (T6) & $4.27 \mathrm{~b}$ & $4.44 d$ & $158.16 \mathrm{c}$ & $174.44 \mathrm{~b}$ & $154.32 \mathrm{c}$ & $164.45 c$ & $21.00 \mathrm{~d}$ & $22.67 \mathrm{c}$ \\
\hline $\operatorname{LDS} 5 \%$ & 0.22 & 0.094 & 3.80 & 3.63 & 7.17 & 6.55 & 1.11 & 1.52 \\
\hline
\end{tabular}

Means followed by a common letter are not significantly different at the $5 \%$ level by LSD

On the other hand, there were significant differences between the control (T6) and all other treatments or in leaflet area during both 2017 and 2018 seasons. Moreover, there were significant differences between $\mathrm{T} 5$ and all treatments in regards to the number of new leaves in both seasons. Control treatment recorded the lowest leaf area during 2017 and 2018 seasons.

\section{Yield, fruit and flesh weight, and fruit length and diameter}

Control treatment recorded the lowest yield during 2017 and 2018 seasons. Treatment $4(50 \%$ Org $+100 \%$ Bio $)$ recorded the highest yield $(139.61 \mathrm{~kg} / \mathrm{palm})$ in comparison to the control and other treatments during the first season (Table 4). 
Table 4. Effect of different sources of fertilizer on total yield ( $\mathrm{kg} / \mathrm{palm})$, fruit weight $(\mathrm{g})$ and flesh weight $(\mathrm{g})$, fruit length $(\mathrm{cm})$ and fruit diameter $(\mathrm{cm})$ of "Sewi" date palm during 2017 and 2018 seasons

\begin{tabular}{|c|c|c|c|c|c|c|c|c|c|c|}
\hline \multirow{2}{*}{ Treatments } & \multicolumn{2}{|c|}{ Yield (kg/palm) } & \multicolumn{2}{|c|}{ Fruit weight } & \multicolumn{2}{|c|}{ Flesh weight } & \multicolumn{2}{|c|}{ Fruit length } & \multicolumn{2}{|c|}{ Fruit diameter } \\
\hline & 2017 & 2018 & 2017 & 2018 & 2017 & 2018 & 2017 & 2018 & 2017 & 2018 \\
\hline 100\% Mineral (T1) & $116.17 \mathrm{~b}$ & $116.53 \mathrm{a}$ & $19.47 \mathrm{abc}$ & $23.60 \mathrm{a}$ & $17.58 \mathrm{a}$ & $21.03 \mathrm{a}$ & $4.45 \mathrm{a}$ & $4.50 \mathrm{a}$ & $2.71 \mathrm{a}$ & $2.71 \mathrm{ab}$ \\
\hline 100\% Organic (T2) & $98.07 \mathrm{~d}$ & $117.89 \mathrm{a}$ & $19.57 \mathrm{ab} 1$ & $22.24 b$ & $16.98 \mathrm{ab}$ & $20.03 b$ & $4.23 \mathrm{bc}$ & $4.27 \mathrm{c}$ & $2.64 \mathrm{a}$ & $2.66 \mathrm{bc}$ \\
\hline 100\% Bio-fertilizer (T3) & $96.83 \mathrm{~d}$ & $106.03 \mathrm{bc}$ & $18.69 \mathrm{bc}$ & $22.42 b$ & $16.80 \mathrm{ab}$ & $20.70 \mathrm{ab}$ & $4.36 \mathrm{ab}$ & $4.50 \mathrm{a}$ & $2.70 \mathrm{a}$ & $2.65 \mathrm{c}$ \\
\hline $\begin{array}{c}50 \% \text { Organic }+100 \% \\
\text { Bio-fertilizer (T4) }\end{array}$ & $111.96 \mathrm{c}$ & $105.46 \mathrm{~b}$ & $19.82 \mathrm{ab}$ & $23.57 \mathrm{a}$ & $17.35 \mathrm{a}$ & $21.10 \mathrm{a}$ & $4.21 \mathrm{c}$ & $4.27 \mathrm{c}$ & $2.63 \mathrm{a}$ & $2.71 \mathrm{ab}$ \\
\hline $\begin{array}{c}50 \% \text { Mineral }+100 \% \\
\text { Bio-fertilizer (T5) }\end{array}$ & $139.61 \mathrm{a}$ & $117.59 \mathrm{a}$ & $20.92 \mathrm{a}$ & $23.75 \mathrm{a}$ & $17.73 \mathrm{a}$ & $21.38 \mathrm{a}$ & $4.16 c$ & $4.36 \mathrm{~b}$ & $2.64 \mathrm{a}$ & $2.70 \mathrm{a}$ \\
\hline Control & $96.33 \mathrm{~d}$ & $52.82 \mathrm{c}$ & $17.74 \mathrm{c}$ & $19.56 \mathrm{c}$ & $15.49 \mathrm{~b}$ & $17.49 \mathrm{c}$ & $4.14 \mathrm{c}$ & $4.13 \mathrm{~d}$ & $2.55 \mathrm{~b}$ & $2.61 \mathrm{c}$ \\
\hline$L D S$ & 3.12 & 2.54 & 1.77 & 0.522 & 1.53 & 0.8 & 0.17 & 0.03 & 0.077 & 0.049 \\
\hline
\end{tabular}

Means followed by a common letter are not significantly different at the $5 \%$ level by LSD

All treatments improved fruit weight, flesh weight, and fruit dimensions compared to the control during 2017 and 2018 seasons. Treatment (4) recorded the highest values of fruit weight (20.92 and $17.73 \mathrm{~g}$ ) and flesh weight (23.75 and $21.38 \mathrm{~g}$ ) during 2017 and 2018 seasons, respectively. Whereas, treatment 2 (100\% Min.) recorded the highest fruit length (4.45 and $4.50 \mathrm{~cm}$ ) in 2017 and 2018 seasons, respectively.

\section{SSC, vitamin C, tannins, total and reducing sugars}

Data in Table 5 showed significant differences between all treatments and the control in regards to \%SSC in both seasons. Control showed the lowest SSC, tannins, and reducing and total sugars during 2017 and 2018 seasons (Table 5). Treatment 4 (50\% Organic $+100 \%$ bio fertilizer) showed the lowest and significant tannins $\%(0.34 \%)$ and the highest total sugars (37.59\%) in 2017 season. Treatment T5 (50\%Mineral $+100 \%$ biofert) recorded the highest content of vitamin C (1.95 and $1.96 \mathrm{mg} / 100 \mathrm{~g}$ flesh weight) and reducing sugars (25.47 and 23.87\%) in 2017 and 2018 seasons, respectively. Control recorded the lowest SSC, reducing sugars and the highest tannins in both seasons.

Table 5. Effect of different sources of fertilizer on SSC (\%), vitamin C ( $\mathrm{mg} / 100 \mathrm{~g}$ fresh weight), total and reducing sugars (\%) of "Sewi" date palm during 2017 and 2018 seasons

\begin{tabular}{|c|c|c|c|c|c|c|c|c|c|c|}
\hline \multirow{2}{*}{ Treatments } & \multicolumn{2}{|c|}{$\operatorname{SSC}(\%)$} & \multicolumn{2}{|c|}{$\begin{array}{c}\text { Vitamin } C(\mathrm{mg} / 100 \mathrm{~g} \\
\text { fresh weight) }\end{array}$} & \multicolumn{2}{|c|}{ Tannins (\%) } & \multicolumn{2}{|c|}{ Total sugar $(\%)$} & \multicolumn{2}{|c|}{ Reducing sugar (\%) } \\
\hline & 2017 & 2018 & 2017 & 2018 & 2017 & 2018 & 2017 & 2018 & 2017 & 2018 \\
\hline $100 \%$ Mineral (T1) & $25.47 \mathrm{c}$ & $26.42 \mathrm{c}$ & $1.47 \mathrm{bc}$ & $1.53 \mathrm{c}$ & $0.36 \mathrm{c}$ & $0.40 \mathrm{~b}$ & $32.81 \mathrm{~b}$ & $32.72 \mathrm{c}$ & $22.98 b$ & $20.99 \mathrm{c}$ \\
\hline $100 \%$ Organic (T2) & $28.53 \mathrm{~b}$ & $30.29 \mathrm{~b}$ & $1.28 \mathrm{~d}$ & $1.43 \mathrm{e}$ & $0.35 \mathrm{c}$ & $0.35 \mathrm{~d}$ & $29.71 d$ & $36.53 \mathrm{ab}$ & $20.57 \mathrm{c}$ & $21.90 \mathrm{bc}$ \\
\hline 100\% Bio-fertilizer (T3) & $26.53 \mathrm{c}$ & $27.83 \mathrm{c}$ & $1.40 \mathrm{c}$ & $1.51 \mathrm{~d}$ & $0.36 \mathrm{c}$ & $0.38 \mathrm{c}$ & $29.90 \mathrm{~d}$ & $31.61 \mathrm{c}$ & $19.87 \mathrm{c}$ & $20.77 \mathrm{c}$ \\
\hline $\begin{array}{l}50 \% \text { Organic }+100 \% \text { Bio- } \\
\text { fertilizer (T4) }\end{array}$ & $29.43 b$ & $29.73 c$ & $1.95 \mathrm{a}$ & $1.97 \mathrm{a}$ & $0.34 \mathrm{c}$ & $0.35 \mathrm{~d}$ & $31.35 \mathrm{c}$ & $35.71 \mathrm{~b}$ & $25.47 \mathrm{a}$ & $23.87 \mathrm{a}$ \\
\hline $\begin{array}{l}50 \% \text { Mineral + } 100 \% \text { Bio- } \\
\text { fertilizer (T5) }\end{array}$ & $31.93 \mathrm{a}$ & $33.43 \mathrm{a}$ & $1.55 \mathrm{~b}$ & $1.66 \mathrm{~b}$ & $0.36 \mathrm{c}$ & $0.34 \mathrm{e}$ & $35.63 \mathrm{a}$ & $37.59 \mathrm{a}$ & $19.54 \mathrm{c}$ & $23.27 \mathrm{ab}$ \\
\hline Control & $22.47 d$ & $22.87 \mathrm{~d}$ & $1.52 \mathrm{~b}$ & $1.51 \mathrm{~d}$ & $0.47 \mathrm{a}$ & $0.45 \mathrm{a}$ & $25.50 \mathrm{e}$ & $28.56 \mathrm{~d}$ & $14.97 \mathrm{~d}$ & $18.77 \mathrm{~d}$ \\
\hline $\operatorname{LDS} 5 \%$ & 1.63 & 1.85 & 0.83 & 0.015 & 0.031 & 0.013 & 1.3 & 1.53 & 1.03 & 1.57 \\
\hline
\end{tabular}

Means followed by a common letter are not significantly different at the $5 \%$ level by LSD 


\section{Discussion}

The effect of bio fertilization could be highly effective if they have been adopted, and integrated with arming systems (Kennedy, 2004; Banayo et al., 2012; Bhardwarj et al., 2014; Masso et al., 2015). Fertilizers improvement via field experiments is important to test it before being economically feasible (Delima, 2012; Sutton et al., 2013). Trees treated with Bio-fertilizer (T3) is the lowest in most testing characters (leaflet area, yield, bunch, fruit and flesh weight, SSC, and total and reducing sugars) than those treated with mineral and/or organic treatments (T1 and T2), but all treatments were better than the control (T6). Palms treated with 50\% Organic +100 Bio-fertilizer (T4) or 50 Mineral +100 Bio-fertilizer (T5) were the best compared to all treatments. These results support the findings of Biswas et al. (2000) and Babalola and Glick (2012) that bio-fertilizers were able to stimulate plant growth and increase yield and its components in field experiments. Andrade et al. 1997) and Banayo et al. (2012) reported that yield numerically higher with inorganic fertilization than that with organic or bio- fertilization. Being more soluble, nutrients availability with inorganic fertilizers provides the most $\mathrm{N}$ requirement of the plants. On the other hand, bio-fertilizers alone are not sufficient to increase the yield in comparison to the recommended rate of inorganic or organic fertilizers. Bio-fertilizers are only supplied half of the $\mathrm{N}$ requirement of the plants. The influence of bio-fertilizers and its combination with organic (T5) or inorganic fertilizers (T6) gave best results than bio-fertilizer alone (T4). Results showed that bio-fertilizers alone could not meet the nutrient requirement of date palms. As cited by Luis and Brown (2003), Banayo et al. (2012) and Sutton et al. (2013), the inorganic fertilizers provided nutrients readily available to the plants, but have negative effects on the environment including soil and groundwater, in addition to other serious threats to human health. They also have direct negative impact on beneficial soil microorganisms. Combining bio-fertilizer with organic fertilizer is slowly and gradually releases nutrients to the plant, improving yield and fruit quality (Mansour, 1998; Banayo et al., 2012). Abdle-Hamid (2002) and Bhardwarj et al. (2014) reported that bio-fertilizers combined with organic or inorganic fertilizers improved yield and fruit quality of olives. Same results were reported in 'Zaghloul' date palm (Osman, 2003), 'Samani' date palms (Elkhayat and Elnoam, 2013), 'Washington' navel oranges (Mostafa, 2002); 'Balady' mandarin (Salama, 2002). Aassy' olive trees (Abd El-Razek et al., 2018); apple (Hidayatullah et al., 2018).

\section{Conclusion}

It can be concluded that bio-fertilizer (Azotobacter chroococcum [Az14], Bacillus megatherium var. phosphaticum [B6], and Bacillus circulans [B4]), as a single inoculation is not sufficient for crop growth. Bio-fertilizer in combination with half of the recommended organic or inorganic fertilizer is sufficient to supply 'Sewi' date palm with required nutrients to improve fruit yield and quality under the Egyptian conditions. The activity of this bio-fertilizer in agro ecosystems is neither easily predictable nor always beneficial.

Acknowledgement. The authors extend their appreciation to the Deanship of Scientific Research at King Khalid University for funding this work through R.G.P. 1/219/41. 


\section{REFERENCES}

[1] A. O. A. C. (1980): Official Methods of Analysis. $13^{\text {th }}$ Ed. - Association of Official Analytical Chemists, Washington, D.C., USA.

[2] Abd El-Razek, E., Haggag Laila, F., Genaidy, E. A. E., El-Hady Eman, S. (2018): Influence of soil application of bio-regulators with greenpower, pigeon manure tea and humic acid on yield and fruit quality of 'Aassy' olive trees (Olea europaea L.). Bioscience Research 15(4): 3459-3471.

[3] Abdel-Hafez, A. M. (1966): Some studies on acid producing microorganisms in soil and rhizosphere with special reference to phosphate dissolvers. - Ph.D. Thesis, Ain Shams University, Cairo, Egypt.

[4] Abdel-Hameed, A. A. (2002): Response of Manzanillo olive trees to nitrogen and bio fertilizer under northern western coast conditions. - M.Sc. Thesis. Fac. Agric, Cairo, Univ, Egypt, pp. 84-88.

[5] Ahmad, M. F., Saxena, R., Sharma, R., Singh, S. K. (2004): Effect of Azotobacter chroococcum on nutrient uptake in Amrapali mango under high density planting. Indian, J. of Hort. 61(4) 348-349.

[6] Alvarez, R., Alvarez, C. R. (2000): Soil organic matter pools and their associations with carbon mineralization kinetics. - Soil Sci. Soc. Am. J. 64: 184-189.

[7] Andrade, G., Mihara, K. L., Linderman, R. G., Bethlenfalvay, G. J. (1997): Bacteria from rhizosphere and hydrosphere soils of different arbuscular mycorrhizal fungi. - Plant Soil 192: 71-79.

[8] Andrews, M., Hodge, S., Raven, J. A. (2010): Positive plant microbial reactions. - Ann. Appl. Biol. 157: 317-320.

[9] Atlas, R. M. (1997): Handbook of Microbiological Media. $2^{\text {nd }}$ Ed. - CRC Press, New York.

[10] Ayed, A. (2002): Effect of chicken manure, sheep manure and inorganic fertilizer on yield and nutrients uptake by onion. - Pakistan Journal of Biological Sciences 5(3): 266268.

[11] Babalola, O. O., Glick, B. R. (2012): The use of microbial inoculants in African agriculture: current practice and future prospects. - Journal of Food, Agriculture and Environment 10(3-4): 540-549.

[12] Baca, B. E., Elmerich, C. (2007): Microbial Production of Plant Hormones. - In: Elmerich, C., Newton, W. E. (eds.) Associative and Endophytic Nitrogen-Fixing bacteria and Cyanobacterial Associations. Springer, Dordrecht, pp 113-143.

[13] Banayo, N. P. M., Cruz, P. C. S., Aguilar, E. A., Badayos, R. B., Haefele, S. M. (2012): Evaluation of biofertilizers in irrigated rice: effects on grain yield at different fertilizer rates. - Agriculture 2: 73-86.

[14] Bhardwarj, D., Ansari, M. W., Sahoo, R. K., Tuteja, N., (2014): Biofertilizers function as key player in sustainable agriculture by improving soil fertility, plant tolerance and crop productivity. - Microbial Cell Factories 13: 66: 1-10.

[15] Biswas, J. C., Ladha, J. K., Dazzo, F. B., (2000): Rhizobia inoculation improves nutrient uptake and growth of lowland rice. - Soil Sci. Soc. Am. 64: 1644-1650.

[16] Bot, A., Benites, J. (2005): The Importance of Soil Organic Matter: Key to DroughtResistant Soil and Sustained Food Production. - FAO Soils Bulletins. FAO, Rome.

[17] Carter, M. R. (2002): Soil Quality for sustainable land management: organic matter and aggregation interactions that maintain soil function. - Agron. J. 94: 38-47.

[18] Chang, F. P., Young, C. C., (1999): Studies on soil inoculation with P-solubilizing bacteria and P fertilizer on P-uptake and quality of tea. - Soil and Environment 2: 35-44.

[19] Cheng, Y. H., Chung, M. F. (2004): The development and application of microbial biofertilizers. - The Annual Report of Research Project Sponsored by Council of Agriculture, Taiwan, ROC. 
[20] Delima, P. C. (2012): Effect of AMF inoculation, diazotrophic and inorganic fertilization and biocide application on the yield of corn (Zea mays L.). - International Journal of Science and Clinical Laboratory 1: 1-17.

[21] Dev, G. (2006): Increasing efficiency of applied fertilizer phosphate using tools of source, dose and method of application: world phosphate institute, Morocco Experience at farmers Field in India. $-18^{\text {th }}$ World Congress of Soil Science, Philadelphia, Pensylvania, July 9-15.

[22] Directorate of Intelligence (2011): "CIA - World Factbook". Information on the History, People, Government, Economy, Geography, Communications, Transportation, Military, and Transnational Issues for 267 World Entities. https://www.cia.gov/library/publications/the-world-factbook/index html.

[23] Dubois, M., Gilles, K. A., Hamilton, J. K., Rebers, P. A., Smith, F. (1956): Colorimetric method for determination of sugars and related substances. - Anal. Chem. 28: 350-256.

[24] Elkhayat, H. M., Elnoam, S. M. (2013): The use of biofertilizer to enhance fruit quality and productivity Zaghloul and Samani date palms. - Alex. J. Agric. Res. 58(2): 131-140: 2013

[25] El-Koumey, B. Y., Abu-Agwa, F. E. (1993): Effect of chicken manure and waste water on some soil properties and nutrients uptake by cowpea plants. - Menofya J. Agric. Res. 18(581): 596.1991.

[26] Fixen P, Brentrup F, Bruulsema T, Garcia F, Norton R and Zingore S (2014): Nutrient/Fertilizer Use Efficiency: Measurement, Current Situation and Trends. - In: Drechsel P., Heffer P., Magen H., Mikkelsen, R., Wichelns, D. (eds.) Managing Water and Fertilizer for Sustainable Agricultural Intensification. IFA, IWMI, IPNI and IPI, Paris.

[27] FAO (2016a): World Fertilizer Trends and Outlook to 2019. - Food and Agriculture Organization of the United Nations (FAO), Rome, Italy.

[28] FAO (2016b): FAOSTAT. - http://faostat3.fao.org (last accessed on 20 September 2016).

[29] FAO (2019): Data for Crop Production in 2017. - http://www.fao.org/faostat/en/\#data (accessed on 25/1/2019).

[30] Franche, C., Lindström, K., Elmerich, C. (2009): Nitrogen-fixing bacteria associated with leguminous and non-leguminous plants. - Plant Soil 321: 35-59.

[31] Galantini, J., Rosell, R., (2006): Long-term fertilization effects on soil organic matter quality and dynamics under different production systems in semiarid Pampean soils. Soil \& Tillage Research 87: 72-79.

[32] Garg, S. K., Bhatnagar, A., Kalla, A., Narula, N. (2001): In vitro nitrogen fixation, phosphate solubilization, survival and nutrient release by Azotobacter strains in an aquatic system. - Bioresour. Technol. 80(2): 101-109.

[33] Harhash, M. M., Abdel-Nasser, G. (2010): Improving of fruit set, yield and fruit quality of "Khalas" tissue culture derived date palm through bunches spraying with potassium and/or boron. - Australian Journal of Basic and Applied Sciences 4(9): 4164-4172.

[34] Hidayatullah, A. K., Mouladad, M., Ahmed, N., Shah, S. A. (2018): Effect of humic acid on fruit yield attributes, yield and leaf nutrient accumulation of apple trees under calcareous soil. - Indian J Sci Tech 11(15): 1-8.

[35] Hue, N. V., Silva, J. A. (2000): Organic soil amendments for sustainable agriculture: organic Sources of Nitrogen, Phosphorus, and Potassium. - In: Silva, J. A., Uchida, R. (eds.) Plant Nutrient Management in Hawaii's Soils. Coll. Trop. Agric. Human Resources, Univ., Hawaii, USA, pp. 133-144.

[36] Iqbal, M., Khan, A. G., UL-Hassan, A., Waseem, M., Muhammad, A. (2012): Soil organic carbon, nitrate contents, physical properties and maize growth as influenced by dairy manure and nitrogen rates. - Int. J. Agric. Biol. 14(1): 20-28.

[37] Jensen, H. L., (1951): Notes on the biology of Azotobacter. - Proc. Soc. Appl. Bacteriol. 14: 89-103. 
[38] Kennedy, I. R., Choudhury, A., Kecskés, M. L. (2004): Non-symbiotic bacterial diazotrophs in crop-farming systems: can their potential for plant growth promotion be better exploited. - Soil Biology and Biochemistry 36(8): 1229-1224.

[39] Liou, R. M., Young, C. C. (2002): Effects of inoculating phosphate-solubilizing rhizobia on the growths and nutrient uptakes of crops. - Soil and Environment 5: 153-164.

[40] Luis, E. M., Brown, M. B. (2003): On farm fertilizer trials using the biological fertilizer scheme for corn: on enhancing adaptation and location-specific corn-based technologies in major corn growing areas. - DA-BAR Terminal Report.

[41] Malik, S. B. (2009): Productivity and quality of wheat spp. grown with different fertilization conditions. - Indian Journal of Agricultural Sciences 79(8): 636-40.

[42] Mansour, A. E. M. (1998): Response of Anna apples to some bio-fertilizers. - Egypt. J. Hort. 25(2): 241-251.

[43] Marozsán, M., Veres, S., Gajdos, É., Bákonyi, N., Tóth, B., Lévai, L. (2005): The possible role of biofertilizers in agriculture. - 44th Croatian \& 4th International Symposium on Agriculture, Ratarstvo, pp. 585-588.

[44] Masso, C., Ochieng, A., Vanlauwe, B. (2015): Worldwide contrast in application of biofertilizers for sustainable agriculture: lessons for Sub-Saharan Africa. - Journal of Biology, Agriculture and Healthcare 5(12): 34-51.

[45] Moustafa, M. A. (2002): Studies on fertilization of Washington navel orange trees. $-\mathrm{PhD}$ Dissertation Fac. of Agric. Moshtoher, Zagazig Uni, Benha Branch, Egypt.

[46] Osman, S. M. (2003): Effect of bio- fertilizer on fruit physical and chemical properties of Zaghloul date palm. - Annals Agric. Sci, Ain Shams Univ, Cairo 48(1): 297-305.

[47] Salama, A. S. M. (2002): Response of some fruit species transplant and trees to organic fertilization. - Ph. D. thesis, Fac. Agric, Moshtoher, Zagazig Uni, Benha Branch, Egypt.

[48] Sarker, A., Kashem, A., Osman, K. T. (2012): Influence of city finished compost and nitrogen, phosphorus and potassium (NPK) fertilizer on yield, nutrient uptake and nutrient use efficiency of radish (Raphanus sativus L.) in an acid soil. - International Journal of Agricultural Sciences 2(12): 315-321. www.internationalscholarsjournals.org.

[49] Sarrwy, S. M. A., Gadalla, E. G., Mostafa, E. A. M. (2012): Effect of calcium nitrate and boric acid sprays on fruit set, yield and fruit quality of cv. Amhat date palm. - World Journal of Agricultural Sciences 8(5): 506-515.

[50] SAS (2000): SAS/STAT User's Guide, Release 6.03. - SAS Institute, Cary, NC, USA. Sci.,152: 108-115.

[51] Snedecor, G. W., Cochran, W. G. (1977): Statistical Methods. $6^{\text {th }}$ Ed. - The Iowa State Univ., Press Aimers, Iowa, USA, pp. 593-596.

[52] Subba Rao, N. S. (1982): Biofertilizers in Agriculture. - A. A. Blackman, Rotterdam/New Delhi, pp. 128-136.

[53] Sutton, M. A., Bleeker, A., Howard, C. M., Bekunda, M., Grizzetti, B., de Vries, W., van Grinsven, H. J. M., Abrol, Y. P., Adhya, T. K., Billen, G., Davidson, E. A., Datta, A., Diaz, R., Erisman, J. W., Liu, X. J., Oenema, O., Palm, C., Raghuram, N., Reis, S., Scholz, R. W., Sims, R. W., Westhoek, T., Zhang, F. S. (2013): Our Nutrient World: The Challenge to Produce More Food and Energy With Less Pollution. - Centre for Ecology and Hydrology (CEH), Edinburgh, UK.

[54] Tsai, Y. F., Chien, S. Y., Young, C. C. (2004): Using microorganisms to upgrade the quality and expand the use of compost. - Proceedings of 2004 Taiwan Bio-Exhibition, pp. 109-110.

[55] Wander, M. (2004): Soil Organic Matter Fractions and Their Relevance to soil Function. - In: Magdoff, F., Weil, R. R. (eds.) Soil Organic Matter in Sustainable Agriculture. CRC Press, Boca Raton, FL.

[56] Wilde, S. A., Corey, R. B., Lyer, J. G., Voigt, G. K. (1985): Soil and Plant Analysis for Tree Culture. 3rd Ed. - Oxford and IBM Publishers. New Delhi, pp. 93-106.

[57] Winton, A. L., Winton, K. B. (1958): The Analysis of Foods. - John Wiley and Sons, Inc., London, pp: 853-867. 
[58] Young, C. C., Lai, W. A., Shen, F. T., Hung, M. H., Huang, W. S., Arun, A. B. (2003): Exploring the microbial potentiality to augment soil fertility in Taiwan. - In: Proceedings of 6th ESAFS International Conference: Soil Management Technology on Low Productivity and Degraded Soils, Taipei, Taiwan, pp. 25-27. 